\title{
ZNF281 Gene
}

National Cancer Institute

\section{Source}

National Cancer Institute. ZNF281 Gene. NCI Thesaurus. Code C114740.

This gene is involved in both transcriptional repression and cell differentiation. 